\title{
A Socio-Political Overview of Post-Socialist Southeastern Europe Today
}

\author{
SABRINA P. RAMET \\ Norwegian University of Science \& Technology (NTNU), Norway \\ ORCID No: 0000-0003-2843-3898
}

\begin{abstract}
According to Freedom House, those southeast European states which have joined the European Union are "free" while the rest are "partly free." For ordinary citizens, the most important issues are corruption, unemployment, and poverty. There is an approximate correlation between Freedom House's assessments of democratic attainment and local perceptions of corruption: the more corrupt the country, the less democratic it is likely to be. The media are crucial players in politics, but have sometimes been corrupted by special interests or by the politicians themselves. Overall, taking into account also tolerance, levels of gender equality, and poverty, among other factors, Slovenia is doing the best in the region, while Kosovo remains in last place.
\end{abstract}

Keywords: Balkans, Politics, Economy, Media 
B etween 1989 and 1991, the states of Southeastern Europe, together with other states abandoning communism, opened a new chapter in their history. ${ }^{1}$ For the states, which emerged out of socialist Yugoslavia, this meant, in the short run, war. Indeed, of Yugoslavia's six republics and two autonomous provinces, one escaped with just ten days of fighting (Slovenia), while four were involved to a greater or lesser extent in the War of Yugoslav Succession from 1991 to 1995 (in alphabetical order: Bosnia-Herzegovina, Croatia, Montenegro, and Serbia, though the latter two were joined in a common state at the time). Kosovo, which declared its independence in 2008, saw fighting between the Kosovo Liberation Army, made up of Albanians, and the Yugoslav Army, during 1998-1999, while Macedonia escaped the war of 1991-1995 only to experience an insurrection of Albanians over a period of six months in 2001. Even while the fighting continued, the Yugoslav successor states took up the same tasks undertaken by the other states of Southeastern Europe, specifically to de-monopolize politics and the media, to organize multi-party elections, to privatize the economy (delayed in Serbia), and to rehabilitate the economy after the erosion just preceding, and typically also following, the collapse of communism. Whether one wishes to call the period since 1989-1991 a transition, by which one would think of transition to membership in the European Union and NATO, or a transformation, by which one would mean simply change without specifying any preconceived notion of a goal (however unlikely that would seem), the question emerges: just how successful have the states in Southeastern Europe been in their transition/transformation?

\section{Ranking the Countries}

There are two standard ways to measure political and economic progress in any given society. The first is in absolute terms, usually involving assessments by area specialists. The annual reports from Freedom House reflect this methodology. The second approach is to offer relative rankings, showing, thus, Slovenia, for example, as more democratic than the other states in Southeastern Europe, while corruption, according to local subjective perceptions as recorded by Transparency International, is reported as most serious in Albania, again within Southeastern Europe. Both of these approaches are useful and may be used in combination.

Thus, to start with the assessments reported by Freedom House, we find that Slovenia, Croatia, Romania, and Bulgaria -all members of the European Union- are rated as "free," while the other states in the region, none of which are EU members, are rated as "partly free." Slovenia and Croatia received the highest marks from Freedom House in 2019 (94 and 85 respectively, out of 100 ), followed by Romania (81) and Bulgaria (80). Bosnia-Herzegovina and Kosovo received the lowest scores in the region (53 and 54 respectively). Within 
the post-Yugoslav area, these scores reflect steady improvement since 1998 on the part of Slovenia, Croatia, Serbia, and Montenegro, slight improvement in Macedonia/North Macedonia, and Montenegro, and stagnation in Kosovo.

The most recent rankings by the Economist Intelligence Unit offer a somewhat different picture. In the view of The Economist, while Slovenia is ranked the highest in the region (\#3 in Eastern Europe, \#36 globally), Bulgaria is ranked as more democratic than Croatia, and Serbia is ranked as somewhat more democratic than Romania. Kosovo is not ranked in the Economist listing (see Table 1).

Table 1: Democracy Rankings, 2018

\begin{tabular}{|l|c|c|}
\hline Country & $\begin{array}{c}\text { Regional ranking } \\
\text { (Eastern Europe) }\end{array}$ & Global ranking \\
\hline Slovenia & 3 & 46 \\
\hline Bulgaria & 7 & 60 \\
\hline Croatia & 10 & 63 \\
\hline Serbia & 11 & 66 \\
\hline Romania & 12 & 76 \\
\hline Albania & 13 & 78 \\
\hline North Macedonia & 14 & 81 \\
\hline Montenegro & 16 & 101 \\
\hline Bosnia-Herzegovina & 20 & \\
\hline Kosovo & Not ranked & 46 \\
\hline
\end{tabular}

Source: The Economist Intelligence Unit ${ }^{2}$

Where ordinary citizens are concerned, however, the most important issues are corruption, poverty, and unemployment, all of which affect quality of life directly. In fact, corruption is arguably the single most important challenge for politics not only in Southeastern Europe but in much of the world; the only other challenge which can rival corruption in its impact on the functioning of democratic institutions is organized crime. However, while organized crime is present in Southeastern Europe, corruption is the larger problem here. A 
In Kosovo corruption is manifested, amongst other ways, in the proliferation of ministries to which the relatives and friends of power-holders are appointed glance at Table 2 shows a rough correlation between Freedom House's assessments of democratic attainment and local perceptions of corruption, with Slovenia, Croatia, and Romania in first, second, and third place respectively on each list. Bulgaria and Serbia are ranked in fifth and sixth place in terms of corruption, among the 10 states of the region, but in second and fourth place in The Economist's scores for democratic attainment. Albania, Bosnia-Herzegovina, North Macedonia, and Montenegro finish in the bottom places on both lists.

Table 2: Corruption Perception Rankings

\begin{tabular}{|l|c|c|c|}
\hline Country & 2018 & 2009 & 2000 \\
\hline Slovenia & 36 & 27 & 51 \\
\hline Croatia & 60 & 71 & 68 \\
\hline Romania & 61 & - & - \\
\hline Montenegro & 67 & 71 & - \\
\hline Bulgaria & 77 & 83 & - \\
\hline Serbia & 87 & - & 89 \\
\hline Bosnia-Herzegovina & 89 & - & - \\
\hline Kosovo & 93 & - & - \\
\hline Yugoslavia & - & 71 & - \\
\hline (North) Macedonia & 93 & 95 & \\
\hline Albania & 99 & & \\
\hline
\end{tabular}

Source: Transparency International ${ }^{3}$

Corruption can take various forms. In Kosovo, for example, corruption is manifested, amongst other ways, in the proliferation of ministries to which the relatives and friends of power-holders are appointed. In 2012, the government of Kosovo had on its staff, in addition to the prime minister, six deputy prime ministers, 19 ministers, 33 deputy ministers, and 162 advisers. ${ }^{4}$ By comparison, the Chancellor of the Federal Republic of Germany, with roughly 40 times the population of Kosovo, is assisted by one deputy chancellor and 15 ministers. It should be recalled, however, that Kosovo is a very young state and that both the United States and West Germany got off to a somewhat rocky start -in the former case as manifested in the Alien and Sedition Acts of 1798. Nepotism 


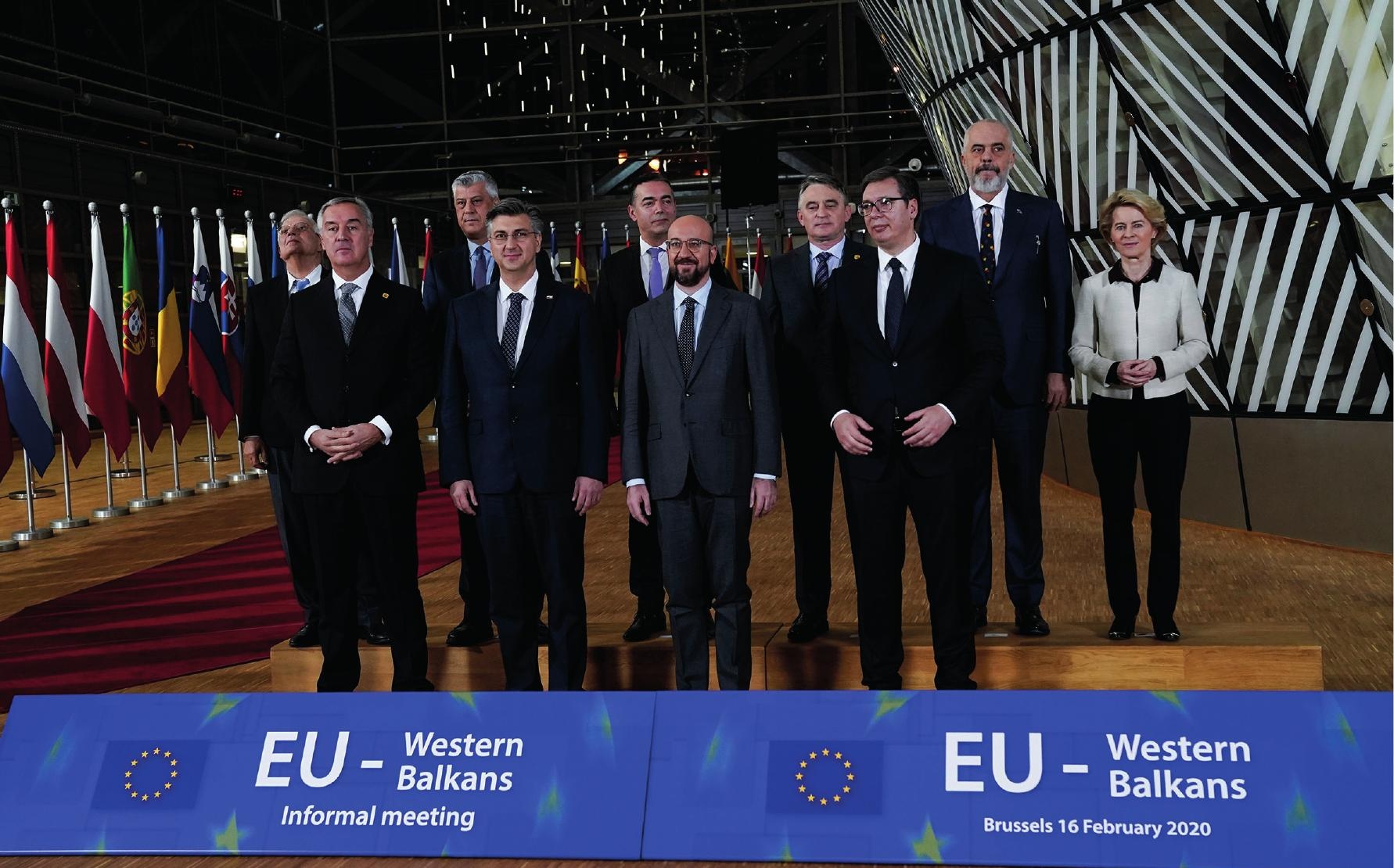


Where the proportion of the population living below the poverty line is concerned, in spite of some fluctuation in the first years of the twenty-first century, Romania and Bulgaria are more or less in the same position as they were nearly three decades ago control of the key media, whether directly or indirectly. ${ }^{8}$ Serbia affords an example of direct control, with Izabela Kisić reporting in 2015 that "the government still owns many media outlets, including influential, high-circulation dailies such as Politika or Večernje Novosti." 9 Slovenia, during the first prime ministership of Janez Janša (between December 3, 2004 and November 21, 2008), affords an example of indirect control or, more accurately, political influence. Specifically, in August 2005, in the course of a then-secret meeting with wealthy businessman Boško Šrot, "Janša offered to arrange for shares in the Mercator company, a large retail chain, to be sold at a favorable price to Laško (a brewery, owned by Šrot) and Istrabenz (company), in exchange for de facto control of editorial and managerial appointments as well as the editorial policy at Delo, of which Šrot owned a decisive share." ${ }^{10}$ Šrot agreed to the deal and Janša proceeded to pick the general manager and editor-in-chief of Delo and to interfere in editorial policy at the newspaper on a daily basis.

Elections in several states in the region have also been marred by corruption. In Macedonia, ${ }^{11}$ for example, there were credible charges during the prime ministership of Nikola Gruevski (between August 27, 2006 and January 18, 2016), of "the theft of election materials, registering deceased citizens to vote, vote buying, voter intimidation, and cutting off the electricity to high-rise apartments where elderly people were living in order to prevent them from voting, affecting the 2011 and 2014 parliamentary elections, as well as the local elections in 2013." 12 In Serbia, the local NGO Centre for Research, Transparency, and Accountability reported 18 irregularities in the 2017 elections, and there were allegations that President Aleksandar Vučić owed his political office to serious abuse of state resources, including electoral fraud and instrumentalization of the media in order to promote his campaign. ${ }^{13}$ In Albania, every election result since 1991 has been disputed. An election was held in June 2019 in spite of the opposition party's refusal to take part and President Ilir Meta's decision to postpone the election. In the event, Prime Minister Edi Rama overrode the president's decision, set the election to take place at the end of the month, and initiated impeachment proceedings against the president. ${ }^{14}$ The election took place with the media failing to provide important, impartial information about the candidates. ${ }^{15}$ Finally, in the first elections held in neighboring Kosovo in 2010, there were credible allegations of voter fraud, including a report that, at one polling station, the official voter turnout was 149 percent. ${ }^{16}$ Seven years later, elections in Kosovo received a somewhat more positive, if mixed, appraisal. In 
this instance, Alojz "Lojze" Peterle, member of the European Parliament and chief of the EU Election Observation Mission for the June elections, reported:

The June 11, 2017 early elections were genuinely competitive and peaceful in most parts of Kosovo. Voters were generally offered pluralistic information on the political forces in competition. However, the elections were negatively impacted by long-standing weaknesses, in particular inaccurate voter lists that are vulnerable to fraud, an electoral system open to abuse, and a largely flawed system for Out-of-Kosovo voting. ${ }^{17}$

\section{Poverty and GDP}

Where the proportion of the population living below the poverty line is concerned, the results are mixed. Comparing the early 1990s with the latest figures found at the CIA World Factbook (figures from 2012-2016), it appears that, in spite of some fluctuation in the first years of the twenty-first century, Romania and Bulgaria are more or less in the same position as they were nearly three decades ago. However, among the Yugoslav successor states, contrasting figures from 2003-2004 with figures from 2014-2017, it is clear that there has been tangible improvement in this area in Slovenia, Croatia, and Macedonia, with no significant change in Bosnia-Herzegovina. The breakup of the Union of Serbia and Montenegro, a union which lasted under this name from 2003 to 2006 and also included Kosovo, renders strict comparison somewhat uncertain where the less populated republics of Montenegro and Kosovo are concerned. However, where the Union of Serbia and Montenegro reported that 10 percent of the population was living below the poverty line in 2003-2004, the figure for Serbia for 2014 was virtually unchanged at 8.9 percent (see Table 3).

Table 3: Proportion of the Population Living below the Poverty Line (in percent)

\begin{tabular}{|l|c|c|c|}
\hline Yugoslav Region & 2014-2017 & 2003-2004 & Late 1980s \\
\hline Slovenia & 6.6 & 29.2 & \\
\hline Croatia & 19.5 & & \\
\hline Montenegro & 8.6 & 18 & \\
\hline Serbia & 8.9 & & \\
\hline Bosnia-Herzegovina & 16.9 & 30.2 & \\
\hline Kosovo & 17.6 & 10 & \\
\hline Macedonia & 21.5 & & \\
\hline Serbia \& Montenegro & & & \\
\hline Yugoslavia & & & \\
\hline
\end{tabular}




\begin{tabular}{|l|c|c|c|}
\hline Other Countries & 2012-2016 & 2002-2004 & Early 1990s \\
\hline Romania & 22.4 & 28.9 & 20 \\
\hline Bulgaria & 23.4 & 12.8 & more than 25 \\
\hline Albania & N/A & 25 & N/A \\
\hline
\end{tabular}

Source: Sabrina P. Ramet ${ }^{18}$

According to figures for GDP per capita for 2019 provided by the International Monetary Fund (IMF), the poorest countries in Europe are Moldova (GDP per capita of $\$ 2,560)$, Ukraine $(\$ 3,560)$, Kosovo $(\$ 3,990)$, Albania $(\$ 4,450)$, Bosnia-Herzegovina $(\$ 4,740)$, North Macedonia $(\$ 5,150)$, Serbia $(\$ 5,820)$, Montenegro $(\$ 7,320)$, Bulgaria $(\$ 7,620)$, and Romania $(\$ 9,520)$-all except Ukraine in Southeastern Europe ${ }^{19}$ From this list, it is evident that Bulgaria is the poorest state in the European Union; it also ranks lowest within the European Union in terms of average salary, minimum wage, and average pension. ${ }^{20}$ As recently as 2018, 22 percent of Bulgarians were living below the poverty line. ${ }^{21}$ As elsewhere, poverty affects above all the elderly, single parents, and families with three or more children. The situation is similar in Serbia where 25 percent of the population lives in poverty, although the poverty rate began to sink very gradually after 2010. Floods and earthquakes have contributed to poverty in Serbia, with floods affecting about 200,000 people each year, at a cost of about $\$ 1$ billion annually.2 Even Slovenia is afflicted with persistent pockets of poverty, with an estimated 14.3 percent of the population living below the poverty line in $2015 .{ }^{23}$ Counting also those at risk of poverty, the figure rises to 23.7 percent in $2015 .{ }^{24}$ Among the factors behind poverty are prolonged unemployment, low pensions, lack of saleable skills, and -in Bosnia-Herzegovina and Serbia- the

In North Macedonia, although the law expressly bars political parties, public office holders, and their families from founding, co-founding, acquiring, or pursuing broadcasting activity, in actual fact some politicians and parties have done just that long-term effects of the War of Yugoslav Succession. Where Romania is concerned, poverty is compounded by an enormous housing problem, with higher levels of poverty in rural areas than in the cities. According to the Borgen Project, "child poverty [in Romania] is at an all-time high." 25

Not surprisingly, there is a rough correlation between levels of poverty and levels of unemployment. However, it is striking that, while official figures show a low unemployment rate of 4.9 percent in Romania in 2017, 25.4 percent of Romanians were living below the poverty line in 2015, with an additional 35.7 percent of Romanians described as being at risk of poverty in 2017 (see Table 4). ${ }^{26}$ The same 
disjunction between poverty and unemployment is found in Bulgaria, where, according to CIA data, 23.4 percent of Bulgarians were living below the poverty line in 2016, while unemployment was reported at 6.2 percent for 2017. In Bosnia-Herzegovina, public frustration over high unemployment led to three days of protests in Sarajevo and Tuzla in February 2014, with clashes between protesters and police resulting in more than 130 injuries in Tuzla. ${ }^{27}$

Table 4: Unemployment in the Balkans (in percent)

\begin{tabular}{|l|c|c|c|}
\hline Country & 2017 & $2003 / 2005$ & 1991 \\
\hline Romania & 4.9 & 8.2 & 8.7 \\
\hline Bulgaria & 6.2 & 9.4 & \\
\hline Slovenia & 6.6 & 19 & \\
\hline Croatia & 12.4 & 21.5 & \\
\hline Serbia & 14.1 & & \\
\hline Montenegro & 16.1 & 43 & \\
\hline Bosnia-Herzegovina & 20.5 & 38 & 15 \\
\hline BiH Federation & & 90 (Serbs) & \\
\hline Republika Srpska & 30.5 & 70 (Albanians) & \\
\hline Kosovo & 22.4 & 37.5 & \\
\hline Macedonia & & 14.6 & \\
\hline Yugoslavia & & & \\
\hline Albania & & & \\
\hline
\end{tabular}

Sources: Central Intelligence Agency, The World Factbook, and Sabrina P. Ramet ${ }^{28}$

\section{The Importance of the Media}

Turning to the quality of democracy, among the several key factors which might be highlighted (i.e., judicial professionalism, competence, and independence; free and fair elections; real choice at elections; and separation of powers) the presence of an informed public stands out as being of especial salience. Here, of course, the media plays a central role. It is incumbent upon both the broadcast media and the print media to remain free from political influence or control and to maintain reasonable standards of professionalism and competence if they are to be supportive of democracy, rather than subversive. The tabloidization of the media, which is increasingly an issue, undermines the professionalism of the media not from the political sector but from market calculations. 


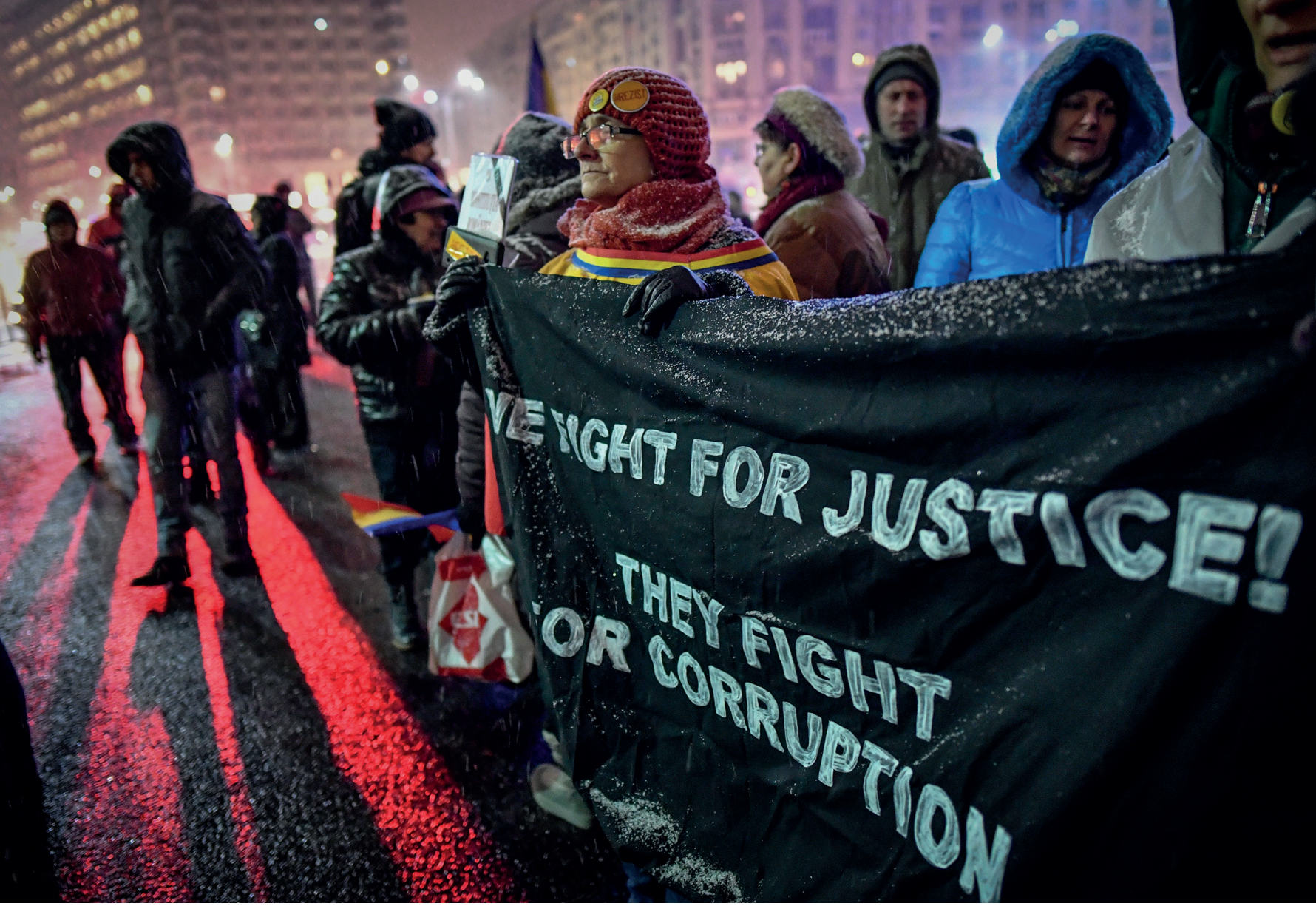

Protesters during a rally in front of the government headquarters,

Bucharest,

February 2018.

DANIEL MIHAILESCU / AFP via Getty Images

Whether in Southeastern Europe or anywhere else in the world, ownership of the media is critical to media freedom. To make an obvious point, coverage of certain issues may involve conflict of interests, for example, in reportage of new findings concerning the dangers of cigarette smoking where the ownership of the television broadcaster is known to have invested heavily in cigarette manufacturing. Alternatively, politics may be the operative variable. In North Macedonia, for example, although the law expressly bars political parties, public office holders, and their families from founding, co-founding, acquiring, or pursuing broadcasting activity, in actual fact some politicians and parties have done just that. As Vesna Šopar has pointed out, this has impacted editorial policy and journalism directly. ${ }^{29}$ The situation is much the same in Romania, where private companies, politicians, and increasingly advertisers are also able to ensure media conformity with their interests. For example, the Romanian mining company RMGC spent $£ 538,000$ in print media advertising in 2011 , a 152 percent jump from its outlay for such advertising in 2010. When thousands of demonstrators took to the streets in the years 2010-2013 to protest RMGC's plan to reopen a gold mine, seen as damaging to the environment, many Romanian media preferred to ignore the protests. Ultimately, the government decided to halt the project. ${ }^{30}$ Bulgaria has been ranked in last place for media freedom among members of the European Union and in $111^{\text {th }}$ place worldwide in the 2019 ranking for Reporters without Borders - a ranking inconsistent with The Economist's relatively high ranking for Bulgaria’s democratic attainment (see Table 5). One problem is media concentration, with Delyan Peevski, an MP and former head 


\section{By contrast with how the media operate elsewhere in Southeastern Europe, the situation in Bosnia-Herzegovina is unique}

of Bulgaria’s principal intelligence agency, in charge of the New Bulgarian Media Group, which owns six newspapers and controls almost 80 percent of the distribution of newspapers and other print media in the country. ${ }^{31}$ According to a report published by Freedom House in 2016, "many [media] outlets are beholden to major advertisers and owners with political agendas. Journalists also face threats and assaults in the course of their work, including from politicians and other powerful interests." 32 As Reporters without Borders put it in May 2018, "[the] majority of the media outlets in Bulgaria are now in the hands of entrepreneurs who exploit them for their own political [and commercial] ends." ${ }^{33}$

Table 5: Press Freedom Index (global ranking)

\begin{tabular}{|l|c|c|c|}
\hline Country & 2019 & 2014 & 2009 \\
\hline Slovenia & 34 & 34 & 37 \\
\hline Romania & 47 & 43 & 50 \\
\hline Bosnia-Herzegovina & 63 & 66 & 39 \\
\hline Croatia & 64 & 65 & 78 \\
\hline Kosovo & 75 & 80 & 75 \\
\hline Albania & 82 & 85 & 68 \\
\hline Serbia & 90 & 54 & 34 \\
\hline (North) Macedonia & 95 & 123 & 77 \\
\hline Macedonia & 104 & 114 & 68 \\
\hline Montenegro & 111 & 100 & 62 \\
\hline Bulgaria & & & \\
\hline
\end{tabular}

Source: Reporters without Borders ${ }^{34}$

By contrast with how the media operate elsewhere in Southeastern Europe, the situation in Bosnia-Herzegovina is unique. There are at least two differences from the situation(s) elsewhere in the region, which are worth highlighting. The first is that, in the course of the War of Yugoslav Succession, the media system fractured along ethnic lines, with some media controlled by Bosniaks, other media by Bosnian Serbs, and still other media under the control of Bosnian Croats. This resulted in the extreme politicization of the media and the proliferation of one-sided reports and outright propaganda. ${ }^{35}$ The second difference, from at least some of the other countries in the region, is that media ownership continues to be under-regulated. Indeed, according to testimony before the Eu- 


\section{Bosnia-Herzegovina, Kosovo, and North Macedonia are the weakest in terms of democratic attainment and fighting corruption, with Bulgaria, Montenegro, and North Macedonia ranked lowest for press freedom}

ropean Parliament in November 2018, "there has been no law limiting media concentration of ownership since 2006 and no information on possible political influences is available to the public." ${ }^{36}$ In 2007, Reporters without Borders ranked Bosnia-Herzegovina in $34^{\text {th }}$ place for press freedom, well ahead of the United States, then ranked $48^{\text {th }}$. In 2019, Bosnia-Herzegovina is ranked in $63^{\text {rd }}$ place, with the United States still ranked in $48^{\text {th }}$ place. In the years between 2012 and 2017, 266 physical attacks on journalists were reported and documented. ${ }^{37}$ Between January 2018 and September 2019, a further 11 physical attacks were registered, alongside 13 explicit murder threats, and one attempted murder of a journalist. ${ }^{38}$ In response, several dozen journalists protested on the streets of Sarajevo at the end of September 2019. According to the weekly newspaper Der Freitag, the situation may be even worse in the Republika Srpska. According to an unsigned blog for that paper, published in 2015, "In Banja Luka, the capital city of the Republika Srpska, all the media stand de facto under the scepter of the still all-powerful and omnipresent Milorad Dodik." ${ }^{39}$ In sum, as Table 5 makes clear, the situation for media freedom is decent only in Slovenia and Romania, and worst in Bulgaria, followed by Montenegro, North Macedonia, and Serbia.

\section{Conclusion}

Finally, it may be useful to comment briefly on the status of civic values in the region. As is well known, such civic values as respect for religious, ethnic, and sexual minorities, respect for others' rights and non-harmful opinions, truthfulness, trust in other people, willingness to embrace compromise, and confidence in parliament and the civil service are basic for any stable liberal democracy. In addition, interest in politics, participating in elections or unconventional political activities, religiosity, and acceptance of modern gender roles are also relevant for democracy. In a recent book chapter, Kristen Ringdal examined the relative standing of 47 European countries across these and other values. What he found is that, among Southeast European countries, those farther south (thus also among the poorest countries) -Albania and Kosovo- are characterized by less trust in other people, the least tolerance of sexual minorities, and high levels of religiosity. Bulgarians report relatively low levels of trust in other people, unusually low confidence in parliament and the civil service, an average level of interest in politics, the lowest level of participation in unconventional political activities, and average religiosity and acceptance of modern gender roles. Bulgarians are also the unhappiest people in the region, judging from the European 
Values Study (EVS) survey results from 2008. By contrast, Macedonians reported the second highest level of confidence in their parliament among Southeast European countries, just behind Slovenia and close to the level reported in Spain. Kosovar Albanians reported the highest level of interest in politics, while Montenegrins reported the lowest. In spite of their Catholicism, Croats reported the highest level of acceptance of modern gender roles -although far below the levels in Scandinavia - and the second highest tolerance of gays and lesbians, just behind Slovenia. Finally, Croats, Albanians, and Montenegrins were the least interested in politics among the societies in the region. ${ }^{40}$ Summarizing his findings, Ringdal wrote that civil society is weakest in the post-communist societies, Turkey, and Iberia. ${ }^{41}$ The crown jewel in the crown of civic values is surely tolerance and, as Zachary Irwin has explained, "the level of tolerance in individual states is strongly correlated with the level of progress in democratic reform and indirectly with the success of EU candidacy." ${ }^{42}$

Taking all of these factors into account, it is obvious that Slovenia is making the most progress in terms of building stable democratic institutions, containing corruption, limiting poverty, promoting and sustaining tolerance, and guaranteeing freedom of the press. At the other end of the scale -in alphabetical orderAlbania, Bosnia-Herzegovina, Kosovo, and North Macedonia are the weakest in terms of democratic attainment and fighting corruption, with Bulgaria, Montenegro, and North Macedonia ranked lowest for press freedom. Long-term political stability may be affected by levels of unemployment (highest in Kosovo, followed by North Macedonia and Bosnia-Herzegovina) and poverty (highest -in alphabetical order- in Bosnia-Herzegovina, Bulgaria, Kosovo, North Macedonia, and Romania). All in all, it is hard to be optimistic about any Southeast European countries, other than Slovenia, Croatia, and possibly Romania, and hard to be anything but concerned, perhaps deeply concerned, when looking at the situation in Kosovo (even allowing that it is a young state), Bosnia-Herzegovina, Albania, and North Macedonia (which had looked so promising until the start of Nikola Gruevski’s prime ministership in 2006).

\section{Endnotes}

1. Except as otherwise noted, all online materials cited in his chapter were accessed between September 30, 2019 and October 3, 2019.

2. "Democracy Index 2018," The Economist Intelligence Unit, retrieved October 3, 2019 from https://www. eiu.com/topic/democracy-index.

3. Transparency International, retrieved October 3, 2019 from https://www.transparency.org/. Note that Macedonia changed its name to "North Macedonia" in June 2018.

4. Jeton Mehmeti and Agron Demi, "Institutions and Political Structures: How Far Is Kosova?," in Olaf Leiße, Martin Roth, and Christian Gesellmann (eds.), Die Republik Kosovo: Der jüngste Staat Europas. Eine politische Bestandsaufnahme seit der Unabhängigkeitserklärung, (Baden-Baden: Nomos, 2013), p. 36.

5. Damir Grubiša, "Political Corruption in Transitional Croatia: The Peculiarities of a Model," Politička misao, Vol. 42, No. 5 (2005), p. 68. 
6. Boris Divjak and Michael Pugh, "The Political Economy of Corruption in BiH," in Ola Listhaug and Sabrina P. Ramet (eds.), Bosnia-Herzegovina since Dayton: Civic and Uncivic Values, (Ravenna: Longo Editore, 2018), p. 85.

7. See, Vesna Pesić, "State Capture and Widespread Corruption in Serbia," CEPS Working Document No. 262 (March 2007), retrieved October 31, 2019 from http://aei.pitt.edu/11664/1/1478.pdf.

8. Peter Gross, "Media, Journalism, and the Third Wave of Democratization in Former Communist Countries," in Sabrina P. Ramet and Christine M. Hassenstab (eds.), Central and Southeast European Politics since 1989, $2^{\text {nd }}$ ed., (Cambridge: Cambridge University Press, 2019).

9. Izabela Kisić, "The Media and Politics: The Case of Serbia," Southeastern Europe, Vol. 39, No. 1 (2015), p. 63.

10. Sabrina P. Ramet and Roman Kuhar, "Ownership and Political Influence in the Post-socialist Mediascape: The Case of Slovenia," Südosteuropa, Vol. 60, (2012), p. 19.

11. At the time Nikola Gruevski was prime minister, the country was still called Macedonia.

12. Sabrina P. Ramet, "Macedonia's Post-Yugoslav Reality: Corruption, Wire-tapping, and Stolen Elections," in Sabrina P. Ramet, Christine M. Hassenstab, and Ola Listhaug (eds.), Building Democracy in the Yugoslav Successor States: Accomplishments, Setbacks, and Challenges since 1990, (Cambridge: Cambridge University Press, 2017), p. 299.

13. Martin Russell, "Serbia at Risk of Authoritarianism?," European Parliamentary Research Service, (May 6, 2019), retrieved from https://epthinktank.eu/2019/05/06/serbia-at-risk-of-authoritarianism/; Filip Rudic, "Belgrade Voters Urged to Report Election Irregularities," Balkan Insight, (February 26, 2018), retrieved from https://balkaninsight.com/2018/02/26/serbian-citizens-called-to-report-election-irregularities-02-23-2018/.

14. "Albania Votes Amid Opposition Boycott," BBC News, (June 30, 2019), retrieved from https://www. bbc.com/news/world-europe-48763803; John Psaropoulos, "A Disputed Election Leaves Albania's Democracy in Tatters," Al Jazeera, (July 1, 2019), retrieved from https://www.aljazeera.com/news/2019/07/ disputed-election-leaves-albania-democracy-tatters-190701195743565.html.

15. Agata Palickova, “Botched Local Elections Undermine Albania's EU Prospects," Euractiv, (July 8, 2019), retrieved from https://www.euractiv.com/section/global-europe/news/botched-local-elections-undermine-albanias-eu-prospects/.

16. Paul Lewis, "Kosovo Election Fraud Suspicions Undermine PM's Victory Claim," The Guardian, (December 13, 2010), retrieved from https://www.theguardian.com/world/2010/dec/13/kosovo-electionfraud-claims.

17. "Elections Genuinely Competitive in Most of Kosovo but Political Will Needed to Address Long-standing Weaknesses, and Intimidation within Kosovo Serb Areas," European Union Election Observation Mission Kosovo 2017, (June 13, 2017), retrieved from https://eeas.europa.eu/election-observation-missions/ eom-kosovo-2017/28080/elections-genuinely-competitive-most-kosovo-political-will-needed-address-long-standing_en, p. 1.

18. Sabrina P. Ramet, The Liberal Project and the Transformation of Democracy: The Case of East Central Europe, (College Station, Tex.: Texas A\&M University Press, 2007), pp. 25, 28.

19. Mayank Uttam, "Top 10 Poorest Countries in Europe," Jagran Josh, (September 27, 2018), retrieved from https://www.jagranjosh.com/general-knowledge/top-10-poorest-countries-in-europe-15380449 90-1.

20. Daniel McLaughlin, "Welcome to Bulgaria, the World's Fastest Shrinking Nation," Irish Times, (October 13, 2018), retrieved from https://www.irishtimes.com/news/world/europe/welcome-to-bulgaria-theworld-s-fastest-shrinking-nation-1.3658819.

21. "Twenty-two Percent of Bulgarians below Poverty Line in 2018 - Statistics Institute," The Sofia Globe, (April 30, 2019), retrieved from https://sofiaglobe.com/2019/04/30/twenty-two-per-cent-of-bulgariansbelow-poverty-line-in-2018-statistics-institute/.

22. Massarath Fatima, "Top 10 Facts about Poverty in Serbia," The Borgen Project (September 11, 2018), retrieved from https://borgenproject.org/top-10-facts-about-poverty-in-serbia/, pp. 1-2. 
23. "Slovenia: Population below Poverty Line," Index Mundi, (January 20, 2018), retrieved from https:// www.indexmundi.com/slovenia/population_below_poverty_line.html.

24. J. G. Federman, "Poverty in Slovenia," The Borgen Project (April 26, 2017), retrieved from https://borgenproject.org/poverty-in-slovenia/.

25. Ronni Winter, "Top 10 Facts about Poverty in Romania," The Borgen Project (September 21, 2018), retrieved from https://borgenproject.org/top-10-facts-about-poverty-in-romania/.

26. "Poverty Watch 2017 - Romania," Renasis, retrieved from https://www.eapn.eu/wp-content/uploads/2018/02/EAPN-Poverty-Watch-Romania-EN-FINAL.pdf, p. 8; “Downward Trend in the Share of Persons at Risk of Poverty or Social Exclusion in the EU," Eurostat Newsrelease, (October 16, 2018), retrieved from https://ec.europa.eu/eurostat/documents/2995521/9310033/3-16102018-BP-EN.pdf/16a1ad623af6-439e-ab9b-3729edd7b775, p. 2.

27. "Bosnia-Hercegovina Protests Break Out in Violence," BBC News, (February 7, 2014), retrieved from https://www.bbc.com/news/world-europe-26086857.

28. "The World Factbook," CIA, retrieved October 3, 2019 from https://www.cia.gov/library/publications/ the-world-factbook/; Ramet, The Liberal Project and the Transformation of Democracy, pp. 24, 27.

29. Vesna Šopar, "The Media and Values in Macedonia between Regulation, Privatization, Concentration, Commercialization, and Pluralization," in Sabrina P. Ramet, Ola Listhaug, and Albert Simkus (eds.), Civic and Uncivic Values in Macedonia: Value Transformation, Education, and Media, (Basingstoke and New York: Palgrave Macmillan, 2013), p. 228.

30. Crina Boros and James Cusick, "Bought and Paid for: How Romania's Media [Are] Pressured by Corporate and Political Masters," Open Democracy, (November 22, 2017), retrieved from https://www.opendemocracy.net/en/bought-and-paid-for-how-romania-s-media-is-pressured-by-corporate-and-polit/; Peter Gross, "(Happily) Living in Sin: Media and Politics in Romania," in Southeastern Europe, Vol. 39, No. 1 (2015), pp. 14-15.

31. "Bulgaria Is Last on Media Freedom in EU and in the Balkans," Euractiv, (April 25, 2018), retrieved from https://www.euractiv.com/section/future-eu/news/bulgaria-is-last-on-media-freedom-in-eu-and-inthe-balkans/.

32. As quoted in "Media Freedom in Bulgaria," Konrad-Adenauer-Stiftung, retrieved from https://www. kas.de/web/balkanmedia/media-freedom2.

33. "Bulgaria: Commercial Interests Instrumentalise the Media," Euro Topics, (May 2018), retrieved from https://www.eurotopics.net/en/149403/bulgaria-commercial-interests-instrumentalise-the-media.

34. Reporters without Borders, retrieved October 3, 2019 from https://rsf.org/en.

35. Sanin Hasibović, "Media Transitions in Bosnia and Herzegovina," in Listhaug and Ramet (eds.), Bosnia-Herzegovina since Dayton, pp. 266-268.

36. "Media Freedom in Bosnia and Herzegovina," European Parliament, (November 14, 2018), retrieved November 28, 2018 from http://www.europarl.europa.eu/doceo/document/E-8-2018-005784_EN.html.

37. Zselyke Csaky, "As Election Nears, Bosnia's Fractured Media Do More Harm Than Good," Freedom House, (September 4, 2018), retrieved from https://freedomhouse.org/blog/elections-near-bosnia-sfractured-media-may-do-more-harm-good, p. 3.

38. "Journalisten in Bosnien Demonstrieren für Pressefreiheit," Der Standard, (September 30, 2019), retrieved from https://www.derstandard.at/story/2000109284250/journalisten-in-bosnien-demonstrieren-fuer-pressefreiheit, p. 2.

39. "Schlag Gegen die Pressefreiheit", Der Freitag, (January 3, 2015), retrieved from https://www.freitag. de/autoren/mehanovic/schlag-gegen-die-pressefreiheit, p. 1.

40. Kristen Ringdal, "Civic Values in Kosovo within a European Perspective," in Ramet, Simkus, and Listhaug (eds.), Civic and Uncivic Values in Kosovo, pp. 273-294.

41. Ringdal, "Civic Values in Kosovo within a European Perspective," p. 285.

42. Zachary T. Irwin, "The Importance of Tolerance: Intolerance and Its Consequences in the Yugoslav Successor States," in Ramet, Hassenstab, and Listhaug (eds.), Building Democracy in the Yugoslav Successor States, p. 77. 


\section{THE PAGES BRINGING YOU THE WORLD}

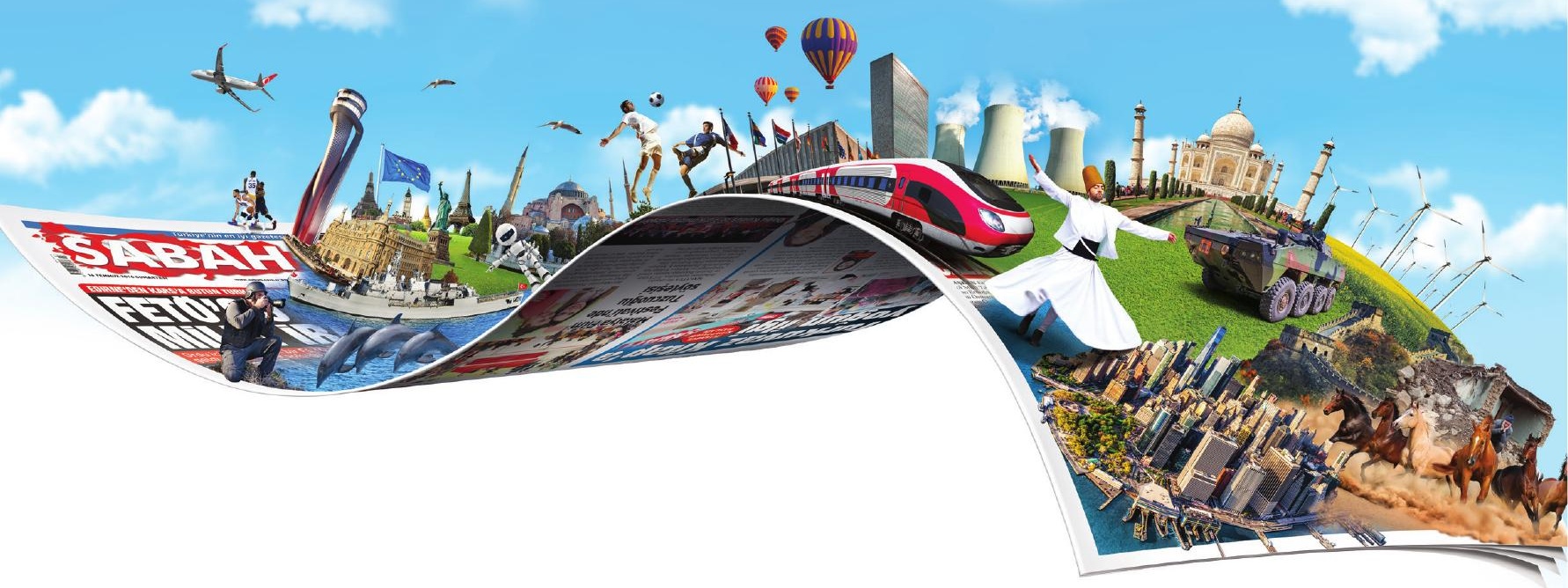

We write the truth, solely the truth, without mincing any words.

Whatever is happening. we bring it to you as it happens.

To us, the world is small, but the power we derive from you is huge.

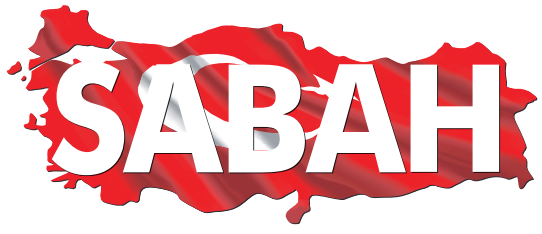

"Turkey's Newspaper" 